Annals of Plant and Soil Research 23(3): 356-362 (2021)

https://doi.org/10.47815/apsr.2021.10084

\title{
Combining ability analysis for yield and yield components and quality traits in Indian mustard [Brassica Juncea L. (Czern \& Coss)]
}

\author{
ANIL KUMAR AND Y.P. SINGH \\ School of Agricultural Sciences and Engg. IFTM University, Lodhipur Rajput Moradabad- 244102 (UP) India \\ Received: April, 2021: Revised accepted: June, 2021
}

\begin{abstract}
Combining ability analysis was performed in a 10× 10 half dialle cross in Indian mustard genotypes for yield and quality traitsduring 2017-18 and 2018-19 at the agriculture research farm R.B.(PG) college Mudi, Agra and IFTM university,Lodhipur Rajput Moradabad.In this study, $45 F_{1}$ hybrid and their parents were evaluated for 14 quantitative and qualitative traits. The parents used namely, NRCHB -101, DRMR- IJ-31, Kanti, Urvashi, Pusa mustard- 25 (NPJ-112), Pusa mustard-26 (NPJ-113), Pusa mustard- 27 (EJ-17), CS- 54, RH- 406, RH 749. The results indicated that both additive and non-additive type of gene actions were responsible in expression of all the 14 characters. Parental genotypes viz., RH -749, RH -406 and CS -54, showed high GCA effects for seed yield per plant and most of the important characters except days to 50\% flowering and days to maturity. The other parent'survashi, PM -27, DRMRIJ-31, NRCHB -101 showed high GCA effects for the remainingtraits. Out of 45 crosses only three crosses $R H-406 \times R H-749, P M-26 \times R H-406$ and PM $-26 \times R H$ -406 had desirable and significant SCA effects with high per se performance for seed yield per plant in $F_{i}$ 's generation. The present study indicated that genetic improvement in the Indian mustard would be achieved by using selected promising crosses having significantly high SCA values coupled with high per se performances.
\end{abstract}

Key words: Combining ability, genetic component, half diallel, Indian mustard.

\section{INTRODUCTION}

Indian mustard [Brassica juncea L. (Czern \& coss)] is an important oilseed crop of the world. Indian mustard is a major oilseed crop of the Indian subcontinent covering more than five million hectares during the winter season. It plays a major role in catering to the edible oil demand of the country. Mustard crops are being cultivated in 53 countries spreading over six continents across the globe. India(14.8\%) is having the third-largest share in rapeseedmustard production in the world next only to China and Canada. In India, the area of mustard is 6.64 Mha with production 8.5 MT and yield $1281 \mathrm{~kg} / \mathrm{ha}$ in. (Anonymous 2018-19). However, the yield of most oilseeds is less than the world average. On the hand, the demand for edible oils is increasing very rapidly with an increasing population and has been estimated to be 20.20 million tonnes for the year 2020 and 28.40 million tonnes for the year 2030 and 41.6 million tonnes for the year 2050 ( Kumar,(2017).

The yield ceiling in the Indian mustard can be brokenby developing high yielding varieties/hybrids through hybridization, which reshufflesthe genes from suitable diverse parents (Monpara et al., 2007). . Evaluation of breeding material for general and specific combining ability for seed yield and yield components are prerequisites in any breeding program aimed for the development of hybrids/varieties.. Moreover, it is also necessary to know about the nature and magnitude of gene action responsible for controlling the inheritance of various yield attributes along with combining ability of the parents and their cross combinations in order to exploit them in further crop improvement programme. The present study was, therefore, undertaken with a view to estimate general and specific combining ability variances and effects in Indian mustard through diallel approach.

\section{MATERIALS AND METHOD}

Ten diverse genotypes viz. NRCHB-101, DRMR- IJ- 31, Kanti, Urvashi, Pusa mustard- 25 (NPJ-112), Pusa Mustard-26 (NPJ-113), Pusa mustard -27 (EJ-17), CS -54, RH -406, RH- 749 were crossed in half diallel fashion to produce 45 $F_{1, s}$. Ten parents and their $45 F_{1, s}$ were grown in a Randomized Block Design with three replications. Each parent and $F_{1, s}$ were grown in single row of $5 \mathrm{~m}$ length with row to row and plant to plant distance of $45 \times 15 \mathrm{~cm}$ respectively, 
during rabi season (post rainy) 2017-18 at research farm, School of Agricultural and Engg. IFTM University, Lodhipur Rajput, Moradabad (U.P.) and during rabi season in the year of 2018-19 to 2019-20 at the agriculture research farm R.B. (PG) College, Mudi, Agra. Recommended cultural practices were adopted in order to raise a healthy crop. A sample of five plants were selected randomly for recording the observations on various parameters i.e.days to $50 \%$ flowering, days to maturity, plant height, primary branches per plants, secondary branches per plant, main shoot length $(\mathrm{cm})$, number of siliquae on main shoot, number of siliquae per plant, siliqua length $(\mathrm{cm})$, number of seeds per siliqua, 1000-seed weight (g), oil content (\%), fiber content (\%) and seed yield per plant $(\mathrm{g})$.Mean values of sample for various traits were subjected to combining ability analysis method II model I of Griffing, (1956).

\section{RESULTS AND DISCUSSION}

The analysis of combining ability revealed considerable genetic diversity among the parents, cross combinations as well as between parental group and cross combination group for all the characters. The Table 1 showed that mean sum of squares due to both general and specific combining ability were significant for all the characters suggesting importance of both additive and non-additive gene effects in the inheritance of these characters. The estimates of gca/scaratio was higher for all thetraits except days to $50 \%$ flowering, primary branches/plant, main shoot length $(\mathrm{cm})$, siliquae on main shoot and number of siliquae/plant. The higher values of ratio was recorded for siliqua length $(\mathrm{cm})$, seed yield per plant (g), plant height, fiber content, secondary branches per plant, oil content. Dominant and recessive alleles of number of siliquae per plant, length of siliqua, 1000 seed weight, oil content fiber content and seed yield per plant were symmetrically distributed among the parents. Similar findings and their implication of these results in Indian mustard breeding has been discussed byTuri et al., (2011) and Dar et al., (2012).

\section{General combining ability}

A perusal of general combining ability (gca) effects of parents indicated that $\mathrm{RH}-406, \mathrm{RH}-$ 749 and CS- 54 found to be good general combiner for seed yield per plant and most of the other traits as well (Table 2).

Table 1: Analysis of variance of combing ability

\begin{tabular}{lcc|c|c|}
\hline Source of variation & GCA & SCA & Error & gca/sca raio \\
\hline D.F. & 9 & 45 & 108 & \\
Days to 50\% flowering & $4.58^{*}$ & $8.89^{* *}$ & 2.40 & 0.52 \\
Days to maturity & $124.19^{* *}$ & $96.76^{* *}$ & 2.80 & 1.28 \\
Plant height (cm) & $1149.63^{* *}$ & $539.99^{* *}$ & 0.82 & 2.13 \\
Pri. Branches/plant & $1.75^{* *}$ & $3.21^{* *}$ & 0.21 & 0.55 \\
Sr. Branches/ plant & $134.81^{* *}$ & $99.29^{* *}$ & 0.19 & 1.36 \\
Main shoot length (cm) & $145.28^{* *}$ & $323.45^{* *}$ & 0.77 & 0.45 \\
Siliquae on main shoot & $163.26^{* *}$ & $191.15^{* *}$ & 2.26 & 0.85 \\
No of siliquae/ plant & $143262.45^{* *}$ & $194939.10^{* *}$ & 673.10 & 0.73 \\
Siliquae length (cm) & $1.87^{* *}$ & $0.31^{* *}$ & 0.02 & 6.07 \\
Seeds per siliquae & $3.43^{* *}$ & $4.93^{* *}$ & 0.19 & 0.70 \\
1000 seed weight (g) & $0.99^{* *}$ & $0.81^{* *}$ & 0.00 & 1.22 \\
Oil content (\%) & $0.59^{* *}$ & $0.49^{* *}$ & 0.07 & 1.21 \\
Fiber content (\%) & $1.03^{* *}$ & $0.62^{* *}$ & 0.03 & 1.65 \\
Seed yield per plant (g) & $334.15^{* *}$ & $101.20^{* *}$ & 1.88 & 3.30 \\
\hline
\end{tabular}

On the other hand parents NRCHB -101, DRMRIJ -31, Kanti, Pusa mustard -25 and Pusa mustard- 26 showed highly significant negative gca effects. For the yield components such as secondary branches per plant, line CS -54, PM 26 and PM -27 were appeared to be good general combiner. Similarly, for main shoot length, the DRMRIJ -31, Kanti, Urvashi, RH 406 and PM 27, for number of siliquae on main shoot, the DRMRIJ -31 and Urvashi, number of siliquae per plant, $\mathrm{RH}-749$, CS -54, $\mathrm{RH}-406$, Pusa mustard -27 (PM- 27) and DRMRIJ -31, 
length of siliqua, $\mathrm{RH}-749$, NRCHB -101, PM -25, PM -27 and DRMRIJ -31, number of seeds per siliqua, DRMRIJ -31, RH -406, Pusa Mustard 27, PM -25 and Urvashi were found to be the best combiners. In case of 1000 seed weight NRCHB 101, RH- 406, DRMRIJ -31, CS -54 and Pusa mustard 27 (PM- 27) were good general combiner. For days to $50 \%$ flowering, parents showing negative and significant values were identified as good general combiner's viz. PM 27 , in case of days to maturity, PM-27, PM -25 , PM -26 and CS- 54 also having negative gca effect and identified as good general combiners. The parents $\mathrm{RH} 406$, Urvashi, RH -749, CS- 54 and NRCHB -101 were the best combiners for plant height. For oil content and sugar content the DRMRIJ -31, PM -26 and RH -749 and for fiber content the PM -26, PM -25, RH -406, CS 54 found to have positive gca effects and identified to be as good combiners. Based on these observations, it can be concluded that parent $\mathrm{RH}$ 406, RH 749 and CS 54, possess desirable alleles for most of the characters. Hence, these parents could be used in future breeding programme for improvement of respective characters and for formation of new heterotic groups. Out of 45 crosses only six crosses viz; PM $26 \times$ CS 54, RH $406 \times \mathrm{RH} 749$, KANTI $\times$ PM 25, NRCHB101 $\times$ DRMRIJ 31, PM $26 \times \mathrm{RH} 406$ and PM $27 \times \mathrm{CS} 54$ crosses showed significant positive effect for seed yield and other characters (Table 2). This new group of crosses indicated possibility in the development of commercial hybrids in Indian mustard in order to exploit hybrid vigour at commercial level. These results are in agreement with earlier findings of Lal et al., (2011), Chaurasiyaet al., (2018) and Singh et al., (2019).

\section{Specific combing ability (sca)}

A perusal of the data presenting in (Table 3) for specific combining ability indicated that none of the cross combination was found to be a common specific combiner for all the characters under study. The cross Kanti $\times$ Urvashi , $\mathrm{NRCHB}-101 \times \mathrm{RH}-749, \mathrm{PM}-27 \times \mathrm{CS} 54$, DRMRIJ $-31 \times \mathrm{RH}-406$ and NRCHB $101 \times$ CS54 had significant and negative sca effects and are considered as best specific combiners for days to $50 \%$ flowering. For early maturity, crosses Kantix Urvashi, PM -27 x RH -406,
Urvashl $\times$ CS -54 , Kanti $\times$ PM $-25, \mathrm{RH}-406 \times$ $\mathrm{RH}-749$ and DRMRIJ $-31 \times \mathrm{RH} 749$ had the negative and high significant sca effect and identified as good specific combiner while parental lines $\mathrm{RH}-749, \mathrm{NRCHB}-101$ and DRMRIJ -31 had highly positive significant gca effects for days to maturity.

The hybrids Kantix PM -25, DRMRIJ 31× PM 27, DRMRIJ -31 × Urvashi, NRCHB101 X Pusa Mustard 27 had showed positive and significant values of sca effects for taller plants. For yield combining traits number of siliquae on main shoot identified Kantix PM 26, DRMRIJ $31 \times$ Urvashi, PM $26 \times$ PM 27, Kantix PM 25 and Urvashix PM 25 crosses for more number of pods per plant. The traits number of siliquae per plant $\mathrm{RH} 406 \mathrm{X} \mathrm{RH} 749$, PM $26 \times$ CS 54, Kanti $\times$ PM 25, DRMRIJ $31 \times$ Urvashi and PM $-27 \times$ CS -54 crosses had positive and significant sca effects and find best specific combiner for more siliquae per plant. The hybrids Urvashix PM -27, PM-27 × RH -749, NRCHB -101x NPJ -112(PM-25), Kantix Urvashi, find best specific combiners for longest siliqua. The DRMRIJ $31 \times \mathrm{RH} 406$, Urvashi $\times$ PM 27, PM $25 \times$ PM- 26, NRCHB $-101 \times$ Kanti, NRCHB-101 $\times$ DRMRIJ -31 and DRMRIJ $-31 \times$ CS- 54 identified for more number of seeds per siliqua. The best specific combiner for 1000 seed weight were Kantix $\mathrm{RH}-406$, DRMRIJ $-31 \times \mathrm{RH}$ 406, PM -25 x RH-749, PM $26 \times \mathrm{PM}-27$, DRMRIJ $-31 \times$ PM- 27 and DRMRIJ $-31 \times P M-$ 26. The hybrids i.e. DRMRIJ $31 \times$ Urvashi, Urvashix PM -25, PM -26 ×CS 54, Kantix CS $54, \mathrm{PM}-26 \times \mathrm{RH} 406$ and PM $-25 \times \mathrm{PM}-27$ were found for best specific combiner for oil content, while fiber content, crosses PM $25 \times$ PM 26, PM $-27 \times \mathrm{RH} 406, \mathrm{PM}-26 \times \mathrm{RH}-406, \mathrm{DRMRIJ}-31$ $\times$ RH 749, NRCHB-101×DRMRIJ 31 and PM -25 $\times \mathrm{RH}-749$ had positive and significant sca values for more fiber content.The best cross combinations for seed yield per plant were PM 26 X CS 54, RH 406 X RH 749, Kanti X PM 25, NRCHB-101 $\times$ DRMRIJ -31, PM $26 \times \mathrm{RH}-406$ and PM $27 \times$ CS -54 . It is interesting to note that the parental lines viz., NRCHB -101, DRMRIJ 31 , Pusa mustard -25 and Kanti having negative significant value exhibited positive sca effects in combination with $\mathrm{RH}-406$ and CS -54 . .

It was observed for most of the characters that there was close association between mean performance and gca effects of the parents. However, combinations having high 
Table 2: GCA effects for parents of Indian mustards

\begin{tabular}{|c|c|c|c|c|c|c|c|c|c|c|c|c|c|c|}
\hline Parents & $\begin{array}{l}\text { Days to } \\
50 \% \\
\text { flowering }\end{array}$ & $\begin{array}{l}\text { Days to } \\
\text { maturity }\end{array}$ & $\begin{array}{l}\text { Plant } \\
\text { height } \\
(\mathrm{cm})\end{array}$ & $\begin{array}{c}\text { Primary } \\
\text { branches/ } \\
\text { plant }\end{array}$ & $\begin{array}{c}\text { Secondary } \\
\text { branches/ } \\
\text { plant }\end{array}$ & $\begin{array}{l}\text { Main shoot } \\
\text { length }(\mathrm{cm})\end{array}$ & $\begin{array}{l}\text { Number of } \\
\text { siliquae on } \\
\text { main shoot }\end{array}$ & $\begin{array}{c}\text { No. of } \\
\text { siliquae/ } \\
\text { plant }\end{array}$ & $\begin{array}{c}\text { Siliquae } \\
\text { length } \\
(\mathrm{cm})\end{array}$ & $\begin{array}{c}\text { Seeds } \\
\text { per } \\
\text { siliquae }\end{array}$ & $\begin{array}{l}1000 \\
\text { seed } \\
\text { weight } \\
(\mathrm{g})\end{array}$ & $\begin{array}{c}\text { Oil } \\
\text { conten } \\
\mathrm{t}(\%)\end{array}$ & $\begin{array}{c}\text { Fiber } \\
\text { content } \\
(\%)\end{array}$ & $\begin{array}{c}\text { Seed } \\
\text { yield per } \\
\text { plant }(\mathrm{g})\end{array}$ \\
\hline NRCHB 101 & 0.70 & $4.14^{\star \star}$ & $0.76^{\star \star}$ & -0.08 & $-1.33^{* \star}$ & $-1.94^{* *}$ & 0.13 & $-104.69^{\star \star}$ & $0.33^{* *}$ & $-0.36^{\star \star}$ & $0.38^{\star \star}$ & $-0.21^{* *}$ & 0.07 & $-4.46^{\star \star}$ \\
\hline DRMRIJ 31 & 0.14 & $1.64^{* *}$ & $-2.02^{* *}$ & 0.11 & $-4.97^{* *}$ & $4.17^{* *}$ & $8.02^{* *}$ & 13.23 & $0.14^{\star *}$ & $0.67^{* *}$ & $0.32^{* *}$ & $0.29^{\star *}$ & $-0.35^{* *}$ & $-3.55^{\star *}$ \\
\hline Kanti & -0.38 & 0.28 & $-4.74^{\star \star}$ & $-0.36^{\star *}$ & $-1.77^{\star *}$ & $2.92^{* *}$ & 0.33 & $-83.99^{* *}$ & $-0.28^{* *}$ & -0.11 & $-0.16^{\star \star}$ & 0.08 & $-0.51^{* *}$ & $-2.51^{\star *}$ \\
\hline Urvashi & -0.58 & 0.39 & $9.65^{\star *}$ & 0.06 & $-0.55^{\star *}$ & $2.78^{\star *}$ & $3.36^{\star *}$ & $-103.27^{\star *}$ & $-0.75^{\star \star}$ & $0.36^{\star *}$ & $-0.34^{\star *}$ & -0.07 & -0.08 & -0.57 \\
\hline $\begin{array}{l}\text { Pusa Mustard } \\
25 \text { (PM 25) }\end{array}$ & -0.05 & $-4.63^{\star *}$ & $-8.63^{* *}$ & $-0.33^{\star *}$ & $-0.77^{\star *}$ & $-4.97^{* *}$ & $-5.20^{* *}$ & $-137.83^{* *}$ & $0.30^{* *}$ & $0.36^{* *}$ & $-0.31^{* *}$ & $-0.32^{\star *}$ & $0.27^{* *}$ & $-6.42^{\star *}$ \\
\hline $\begin{array}{l}\text { Pusa Mustard } \\
26 \text { (PM 26) }\end{array}$ & -0.33 & $-0.97^{*}$ & $-14.27^{* *}$ & $-0.56^{\star *}$ & $5.26^{* *}$ & $-6.25^{\star *}$ & $-3.51^{* *}$ & $-15.55^{\star}$ & $-0.29^{* *}$ & $-0.86^{\star *}$ & $-0.29^{\star *}$ & $0.25^{\star *}$ & $0.42^{\star *}$ & $-2.73^{\star \star}$ \\
\hline $\begin{array}{l}\text { Pusa Mustard } \\
27 \text { (PM 27) }\end{array}$ & $-0.94^{* *}$ & $-5.22^{\star *}$ & $-11.35^{\star *}$ & $0.72^{* *}$ & $1.34^{* *}$ & $0.78^{* *}$ & $-2.51^{* *}$ & $14.98^{*}$ & $0.18^{* *}$ & $0.25^{*}$ & $0.08^{\star *}$ & 0.07 & $-0.21^{* *}$ & -0.03 \\
\hline CS 54 & -0.22 & $-1.11^{\star *}$ & $7.37^{\star *}$ & 0.11 & $6.01^{* *}$ & -0.39 & $-1.01^{* *}$ & $140.78^{* *}$ & $-0.11^{\star *}$ & $-0.86^{\star *}$ & $0.13^{\star *}$ & $-0.31^{\star *}$ & $0.21^{* *}$ & $3.79^{\star \star}$ \\
\hline $\mathrm{RH} 406$ & $0.98^{*}$ & 0.81 & $13.98^{\star *}$ & -0.11 & $-1.63^{\star *}$ & $2.64^{* *}$ & 0.27 & $114.45^{\star *}$ & $-0.13^{\star \star}$ & $0.39^{* *}$ & $0.35^{\star \star}$ & 0.03 & $0.22^{\star *}$ & $10.76^{\star \star}$ \\
\hline RH 749 & 0.67 & $4.64^{* *}$ & $9.23^{* *}$ & $0.44^{* *}$ & $-1.58^{\star \star}$ & 0.28 & 0.11 & $161.89^{* *}$ & $0.62^{* *}$ & 0.17 & $-0.16^{\star \star}$ & $0.18^{*}$ & -0.05 & $5.73^{\star *}$ \\
\hline SE (gi) & 0.42 & 0.46 & 0.25 & 0.13 & 0.12 & 0.24 & 0.41 & 7.10 & 0.04 & 0.12 & 0.01 & 0.07 & 0.05 & 0.38 \\
\hline SE (gi-gj) & 0.63 & 0.68 & 0.37 & 0.19 & 0.18 & 0.36 & 0.61 & 10.59 & 0.06 & 0.18 & 0.02 & 0.10 & 0.08 & 0.56 \\
\hline
\end{tabular}


Table 3: Best five sca effects for hybrids of Indian mustards

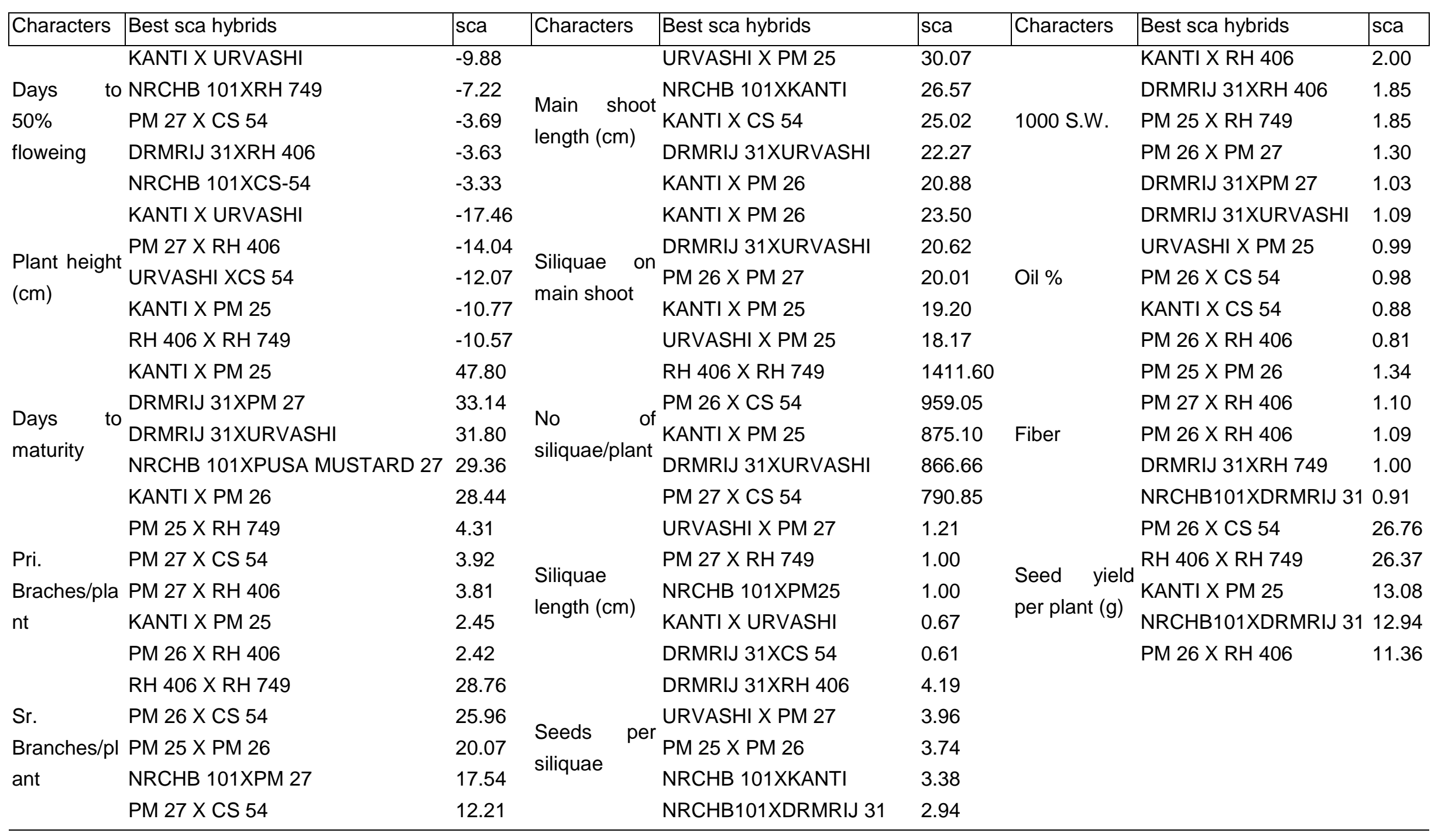


mean did not exhibit high sca effects for all the characters suggesting that only good general combiner on the basis of mean performance may be reliable but not good specific combiner. Parents involved in these crosses were $\mathrm{H} \times \mathrm{H}$, $H \times L, L \times H$ and $L \times L$ combiners. The cross combinations involving either both or one parent with high gca effect indicated additive gene action in controlling the expression of respective trait. These cross combinations would give rise to transgressive segregants in later generations. While cross combinations involving $L \times L$ combiners reflected non-additive gene action, which is non-fixable in nature and could be exploited only through heterosis breeding for further improvement of the respective trait. Similar findings were reported by earlier workers Lal et al., (2011), Pardeep et al.,(2013), Shrimali et al., (2016) Chaurasiya et al., (2018) and Singh et al., (2019).

\section{Components of genetic variance}

The ratio of $\left(H_{1} / D\right)^{1 / 2}$ was indicating the average additive dominance relationship for days to $50 \%$ flowering. The ratio of $\mathrm{H}_{2} / 4 \mathrm{H}_{1}$ was near to 0.18 for days to $50 \%$ flowering, days to maturity, Number of primary branches/ plant, hence, it may be concluded that the positive and negative alleles were distributed symmetrically among the parents. It is apparent that the variation observed in plant height is determined by additive and dominance components of genotypic variance. Dominance variance exceeded the additive genetic variance and the degree of dominance was found to be in over dominance range. The ratio of $\mathrm{H}_{2} / 4 \mathrm{H}_{1}$ did not deviate much from 0.25 , hence, it may be concluded that increasing and decreasing alleles were distributed symmetrically among the parents for most of the characters. The variation observed in this trait was governed by

\section{REFERENCES}

Anonymous. (2018-19). Data of Rapeseed and Mustard; Website: www.nmoop.gov.in

Chaurasiya, Jagdish Prasad, Mahak Singh, RK Yadav and Lokendra Singh (2018). Heterosis and combining ability analysis in Indian mustard (Brassica juncea (L.) Czern and Coss.). Journal of dominance variance and average degree of dominance was in the over dominance range. The higher narrow sense heritability among the parents showing both increasing and decreasing were distributed symmetrically. Dominant alleles showed equal positive and negative effects. The ratio of $\left(\mathrm{H}_{1} / \mathrm{D}\right)^{1 / 2}$ for seed yield per plant (g)showed the average additive dominance relationship and the ratio of $\mathrm{H}_{2} / 4 \mathrm{H}_{1}$ was 0.22 indicating that the positive and negative alleles were distributed symmetrically among the parents. The narrow sense heritability was low (13.99\%). The correlation between parental mean and parental order of dominance was positive and significant showed that the dominant genes contributed equally positive effects in the parental lines.

The results of the study revealed that non- additive genetic variance play a predominant role in the inheritance of the traits. The best combination mostly involved high $\times$ low general combinations for the characters under study. On the basis of gca and sca effects, three parents i.e. $\mathrm{RH}-749, \mathrm{RH}-406$ and $\mathrm{CS}-54$ showed high gca effects for seed yield per plant, and the five superior cross combinations PM-26 $\times$ CS54, RH -406× RH-749, Kanti $\times$ PM-25, NRCHB$101 \times$ DRMRIJ-31 and PM-26 $\times \mathrm{RH}-406$ were found good specific combiners for seed yield per plant and also for some other yield contributing traits. These crosses may be used in heterosis breeding programme for developing new hybrids with better yield and quality. For higher genetic improvement in the Indian mustard, the systematic breeding program should include promising crosses having significant high SCA values as well as high per se performance. Such promising combinations are expected to produce desirable transgressive segregants to achieve high yield and quality (meaning not clear, so deleted).

Pharmacognosy and Phytochemistry 18; 7(2): 604-609.

Dar, Z.A., Wani, S.A., Gulzaffar and Habib, M. (2012). Genetic studies in brown Sarson (Brassica rapa L.). Trends in Biosciences, 5 (4): 317-320. 
Griffing, B. 1956. Concept of general and specific combining ability in relation to diallel crossing system. Australian Journal of Biological Science, 9: 463-493.

Kumar, Arvind (2017). Proceeding of 3rd national brassica conference held at IARI New Delhi on dated 2017; 16-18:7.

Lal, M., Singh, D.P. and Bagadi, D.L. (2011). Combining ability analysis for seed yield and its components in Indian mustard [Brassica juncea (L.) Czern \& Coss]. Agricultural Science Digest, 31 (1): 35 37.

Montara, B.A. and Dobariya, K.L. 2007. Heterosis and combining ability in Indian ustard Brassica juncea (L.) Czern \& Coss]. Journal of Oilseeds Research., 24(2): 306-308.

Pardeep Kumar, Alankar Lamba, R. K. Yadav, Lokendra Singh and Mahak Singh (2013). Analysis of yield and its components based on heterosis And combining ability in indian mustard (Brassica Juncea Czern \& coss). The Bioscan, 8(4): 1497-1502, 2013
(Supplement on Genetics \& Plant Breeding)

Shrimali, T. M. R. M. Chauhan, K. P. Prajapati*, S. A. Desai, J. R. Patel, P. T. Patel, P. J. Patel, and Bharat K. Chaudhary (2018). Analysis of Yield and Its Components Based on Heterosis and Combining Ability in Indian mustard (Brassica juncea L. Czern \& Coss.). International Journal of Pure Applied Bioscience. 6 (1): 219224.

Singh, H., Ravindra Kumar Satveer Kaur, Ikbal Singh and Ramandeep Kaur (2019). Genetic Analysis of Indian mustard for Yield by Calculating Heterosis and Combining Ability. Journal of Agriculture Science, 10(1-2): 1-12.

Turi, N.A., Raziuddin, Farhtullah, Khan, N.U., lqbalmunir, Shah, A.H., Khan, S. Ghulam, H., Jehan, B., Sajid, K. and Mohammad, S. (2011). Combining ability for yield related traits in [Brassica juncea. (L.) Czern \& Coss. Pakistan Journal of Botany. 43 (2): 1241-1248. 